\title{
Household Saving Behavior and Determinants of the Forms of Saving and Investment in Thailand
}

\author{
Nathridee Suppakitjarak and Piyarat Krishnamra
}

\begin{abstract}
This study investigates the household savers of saving level, saving objectives, forms of saving, the determinants of the forms of saving, including consistency between the risk-return concept and the investing decision. The results show that average saving rate was $29.17 \%$ of income and they were familiar with many forms of saving and investments available. The main purpose of savings was for post-retirement spending. Respondents used own decision, together with information provided by bank staff, to select forms of saving and investment. Savers tended to invest more in conventional saving forms, such as bank deposits, insurance policies, gold and properties, than in financial assets such as government bond, mutual fund, corporate bonds, and stock. However, as income levels rose, respondents tended to save less in conventional forms of saving and more toward capital market. Investors also recognized the high return nature of investing in financial assets, but savers have no interest to these types of investments owing to the high risk character, complicated investment process, and high initial investment. However, the highest proportion of savings was allocated to properties (real estate. Savers also perceived that their physical assets generated higher returns and are less risky than financial assets.
\end{abstract}

Index Terms-Saving, saving behavior, saving instruments.

\section{INTRODUCTION}

Household saving is a form of internal capital accumulation in a country. The level of household saving can fundamentally be used to define country growth. Government and businesses can use household saving as their sources of fund without having to seek external fund outside the country even during the economic slowdown. In addition, there is a trend toward ageing of the world's population. The world's population of people 60 years of age and older has doubled since 1980 and the old age is forecast to reach 1.5 billion by 2050 [1]. Hence if household has appropriate saving, this will help them to secure their living after retirement age. However, household saving in Thailand is lower when compare to business sector [2]. The average of saving growth in Thailand is at $4.5 \%$ per year but the investment growth is at $9.5 \%$ per year. This indicates a future sign of inadequate source of fund to business sector. Even though, Thailand has proportion of saving close to South-Korea, Singapore, Malaysia, but Thailand Capital Market is smaller than those countries. (Market Capitalization/GDP) (Fig. 1).

This research investigates saving behavior and saving determinant of Thai people. The result of this research will

Manuscript received October 21, 2013; revised December 28, 2013.

Nathridee Suppakitjarak is with the Chulalongkorn University, Thailand (e-mail: nathridee@acc.chula.ac.th). benefit to policy maker and financial institutions to get the overview of the household saving behavior whether household save through traditional banking or through capital market. The policy maker and financial institutions can develop policy and product to promote the increasing of household saving.

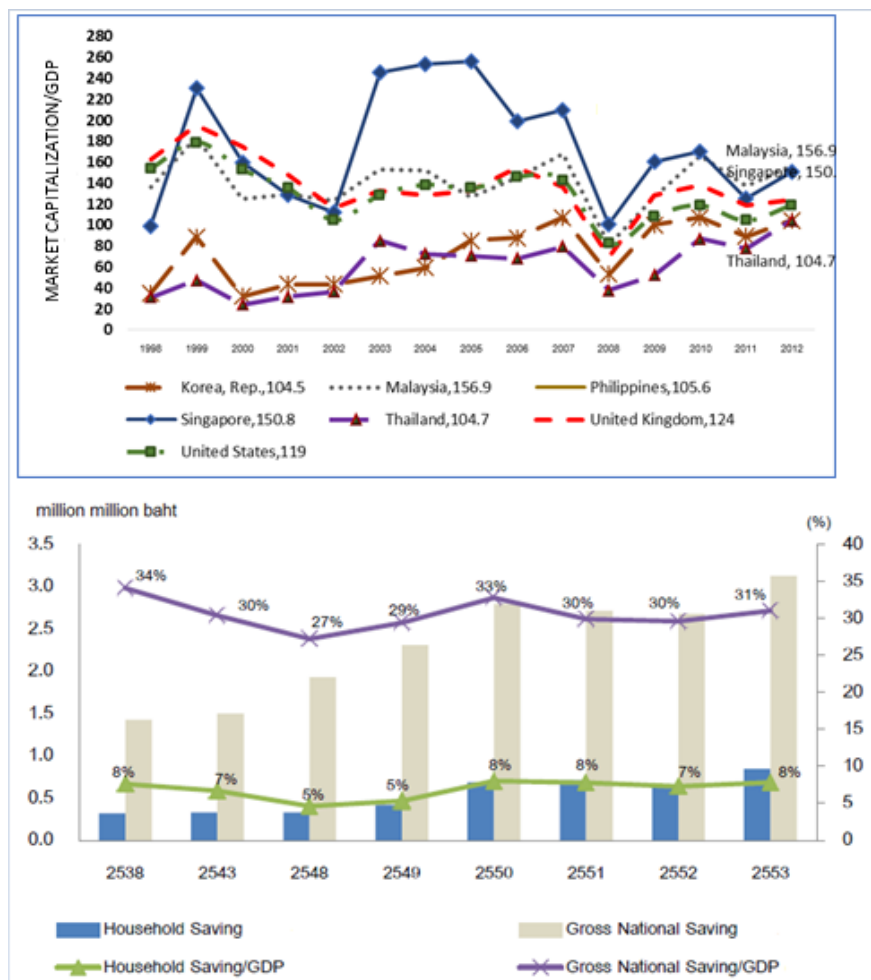

(Lowe panel) national saving/GDP

Source: http://data.worldbank.org, and national account, office of the National Economic and Social Development Board, 2012, Thailand

Fig. 1. (Upper panel) market capitalization/GDP

This research investigates saving behavior and saving determinant of Thai people. The result of this research will benefit to policy maker and financial institutions to get the overview of the household saving behavior whether household save through traditional banking or through capital market. The policy maker and financial institutions can develop policy and product to promote the increasing of household saving.

\section{LITERATURE REVIEW}

There are several studies investigate factors influence saving behavior. The studies show factors such as income [3], liquidity [4]-[6] and external factors such as economic. 
Reference [7] and [8] studied and confirmed factors influence saving decision, such as, financial situation of savers, risk and return perception, knowledge. There are also studies of others factors influence saving decision such as interest rate, liquidity, and easy to access [9]. In addition, product substation is also studied [10], [11].

An important theory about saving is life-cycle saving hypothesis developed by [12], [13]. The theory indicates that people will work to accumulate their wealth until retire and will not accumulate more wealth after retirement age. Reference [7] extended the model to include income, age, risk and return as saving decision factors. Reference [3] also supports both life-cycle theory and Shorrock's studied. There are studies about effect of liquidity constraint to saving decision where people who have more debt will have less ability to save [4]-[6]. There are also inverse relationship between age and saving (age dependency) and child dependency ratio [7] However, there are some researches showing that age is irrelevant to saving decision [14], [15].

Reference [16] studies risk and return to saving decision. They found that return from saving asset and income level of savers are main factors for saving form determinant, and savers tend to save more into higher return asset. Reference [17] investigates household saving behavior by focusing to aging population and use life-cycle model of saving developed by [12]. They find that aging people tend to be more sensitive to asset return. For the financial literacy, reference [18] finds that the determinant of saving forms depend on financial literacy. Reference [19] find that level of education has significant to saving decision into corporate stock. Reference [20]-[22] studied people involve in saving decision. They find that own family (e.g. husband, wife, and children) has influence to their determinant of saving forms because of risk sharing and family mutual objective. Reference [23] finds that level of education has prominent impact on the determinant of saving forms. Reference [24] finds that type of residence (renter or owner) has impacted on saving decision. Reference [25] finds that household ownership (renter or owner) has impact on saving decision. Reference [26] investigates household saving behavior in Bangkok and perimeter. They find that the objective of saving is for retirements and they tend to save though traditional saving e.g. banking, buying insurance, properties than buying financial securities.

\section{RESEARCH AND METHODOLOGY}

The target populations are people who live in Thailand (Bangkok and perimeter, Chiangmai, Nakorn Rachasima, Rayong and Songkhla). The sampling method are purposive and judgment sampling according to income and age. The minimum level of income is 20,000 Baht. The sample will have to save into other saving type apart from banking deposit. The minimum age is 20 years. There are 844 samples. The questionnaire is designed to cover 5 parts.

1) Sample characteristics.

2) Level of saving (disposable income) objective of saving and saving decision.

3) Current saving forms.

4) Saving allocation between various saving forms.

5) Knowledge of risk and returns.

\section{RESUlts}

\section{A. Characteristic of Sample Population}

We will call samples as savers. There is female, 61.26 percent and male 38.74 percent. The average age is 47 years and married 59.79 percent which 40.60 percent has no children. The rest of married saver has average 2 children. There are 78.10 percent of saver poses undergraduate degree and higher. About 30.20 percent have their own business, 28.64 percent are salary workers, 27.57 percent are government agency, and 6.92 percent are retiree.

About 68.73 percent have their own house, 17.84 percent stay with their parent. Their average income is at about 81,836 Baht per month and 51.59 percent has no other income apart from their main income. About 51.40 percent of saver has no liability burden. The rest have average 13.29 percent proportion of debt from their income.

\section{B. Level of Saving, Objective of Saving}

The average disposable income of sample is at about 29.17 percent. There is a positive relationship between income and disposable income (Table I, Table II, and Fig. 2) but there is no relationship between age and disposable income (saving)

TABLE I: AVERAGE of DisPosABle InCOME ACRoss AGE AND INCOME LEVEL

\begin{tabular}{|c|c|c|c|c|}
\hline \multicolumn{2}{|c|}{} & \multicolumn{3}{|c|}{ Level of Income ('000 Baht) } \\
\cline { 3 - 5 } \multicolumn{2}{|c|}{} & $20-49$ & $50-100$ & 100 up \\
\hline \multirow{3}{*}{$\begin{array}{c}\text { Age } \\
\text { (Year) }\end{array}$} & $20-35$ & 25.44 & 30.94 & 33.39 \\
\cline { 2 - 5 } & $36-49$ & 22.26 & 29.91 & 35.40 \\
\cline { 2 - 5 } & $50-60$ & 25.66 & 31.09 & 31.07 \\
\cline { 2 - 5 } & 60 up & 24.59 & 32.27 & 36.89 \\
\hline
\end{tabular}

TABLE II: ANALYSIS OF VARIANCE OF AGE AND INCOME TO DisPosABLE INCOME

\begin{tabular}{|c|c|c|c|c|c|c|}
\hline \multicolumn{7}{|c|}{ ANOVA TABLE } \\
\hline \multicolumn{2}{|c|}{$\begin{array}{l}\text { Disposable } \\
\text { income }\end{array}$} & $\begin{array}{l}\text { Sum of } \\
\text { Squares }\end{array}$ & $d f$ & Mean Square & $F$ & Sig. \\
\hline \multirow{2}{*}{ Age } & $\begin{array}{l}\text { Between } \\
\text { gr. }\end{array}$ & 1099.8 & 3 & 366.606 & 1.089 & 0.353 \\
\hline & $\begin{array}{l}\text { Within } \\
\text { gr. }\end{array}$ & $\begin{array}{r}267971 . \\
497 \\
\end{array}$ & 796 & 1.115 & & \\
\hline \multirow{2}{*}{$\begin{array}{l}\text { In } \\
\text { come }\end{array}$} & $\begin{array}{l}\text { Between } \\
\text { gr. }\end{array}$ & $\begin{array}{r}14605.5 \\
84\end{array}$ & 2 & 7302.792 & 22.873 & .000 \\
\hline & $\begin{array}{l}\text { Within } \\
\text { gr. }\end{array}$ & $\begin{array}{r}254465 . \\
731\end{array}$ & 797 & 319.279 & & \\
\hline
\end{tabular}
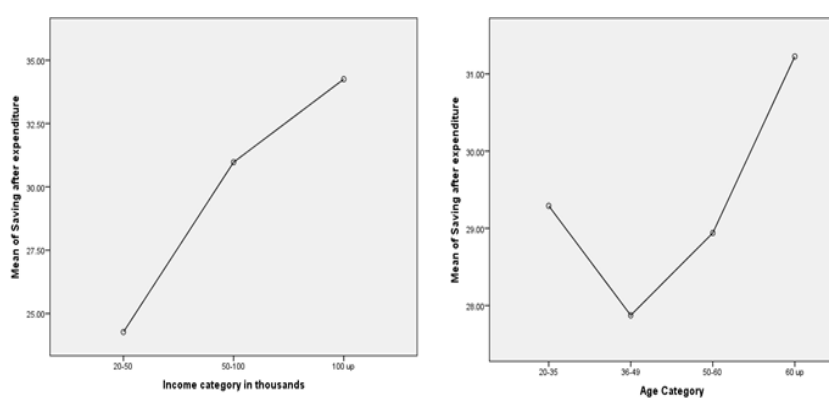

Fig. 2. a): Disposable income and income (left figure). b): Disposable income and age (right figure)

The priority of saving objective are as the following; retirement, health expenditure, precautionary, travel, and for the benefit of their heirs. The main factors that affect to 
saving type decision are as the following; return, risk, convenience, financial literacy, and easy to access (see Table III and Table IV).

For source of information in saving decision, the samples pay more attention to family and other sources are as the following; bank staff, broker, listen to radio/TV analysis and investment brochure. For people involve in their saving decision, about $56.3 \%$ decision on their own, and the rests have other people involve in the determinant of saving forms, as the following; couple, friend, relative, and children (See Table V and Table VI).

TABLE III: SAVING OBJECTIVE RANKING

\begin{tabular}{|l|l|l|}
\hline Rank & Saving Objective & $\%$ \\
\hline 1 & Retirement & 40.8 \\
\hline 2 & Health expenditure & 22.9 \\
\hline 3 & Precautionary & 24.4 \\
\hline 4 & Travel & 13.7 \\
\hline 5 & Benefit of their heirs & 13.2 \\
\hline
\end{tabular}

TABLE IV: FACTOR RAKING AFFECTS TO SAVING TYPE DECISION

\begin{tabular}{|c|c|c|}
\hline Rank & Saving Objective & $\%$ \\
\hline 1 & Return & 44.8 \\
\hline 2 & Risk & 36.1 \\
\hline 3 & Convenience & 27.3 \\
\hline 4 & Financial literacy & 23.5 \\
\hline 5 & Easy to access & 31.3 \\
\hline
\end{tabular}

TABLE V: SOURCE OF INFORMATION RANKING

\begin{tabular}{|c|c|c|}
\hline Rank & Source & $\%$ \\
\hline 1 & Family & 17.4 \\
\hline 2 & Bank Staff & 14.3 \\
\hline 3 & Broker & 10.4 \\
\hline 4 & Radio/TV & 9.7 \\
\hline 5 & Investment Brochure & 8.9 \\
\hline
\end{tabular}

TABLE VI: PEOPLE INVOLVE IN SAVING DECISION RAKING

\begin{tabular}{|c|c|c|}
\hline Rank & People involvement & $\%$ \\
\hline 1 & Own decision & 56.3 \\
\hline 2 & Couple & 18.8 \\
\hline 3 & Friend & 17.7 \\
\hline 5 & Relative & 11.0 \\
\hline 5 & Children & 5.1 \\
\hline
\end{tabular}

\section{Type of Saving}

The savers rank their knowing of saving forms as the following; saving with bank, buying real estate, and gold. More than 50 percent of savers know all traditional saving forms except more sophisticated financial product. Table VII shows knowing and investing in 12 saving type sorted from the most to the least of knowing. We also investigate whether they also invest in that particular saving form that they know. The result can be categorized into 2 main groups 1 ). More than 50 percent of savers choose to invest in conventional forms of saving which they feel acquainting with (Table VII) 2). Less than 50 percent of saver chooses to invest into more sophisticate financial product (See also Fig. 3).
Proportion of saving in various saving type

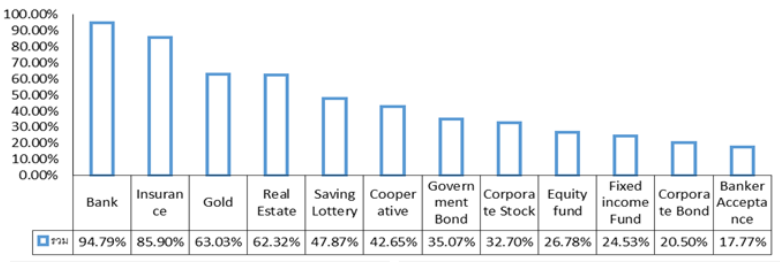

Fig. 3. Percentage of savers choosing to invest in various saving type.

TABLE VII: KNOWING AND INVESTING IN 12 SAVING TYPES

\begin{tabular}{|c|c|c|c|}
\hline & Saving type & Knowing & Investing \\
\hline 1 & Saving with bank & $100.00 \%$ & $94.79 \%$ \\
\hline 2 & Real Estate & $100.00 \%$ & $62.32 \%$ \\
\hline 3 & Gold & $100.00 \%$ & $63.03 \%$ \\
\hline 4 & Insurance & $97.75 \%$ & $85.90 \%$ \\
\hline 6 & Saving Lottery & $93.48 \%$ & $47.87 \%$ \\
\hline 7 & Government Bond & $80.81 \%$ & $35.07 \%$ \\
\hline 9 & Saving with co-operative & $78.08 \%$ & $42.65 \%$ \\
\hline 10 & Corporate Stock & $59.24 \%$ & $32.70 \%$ \\
\hline 11 & Fixed income fund & $56.87 \%$ & $24.53 \%$ \\
\hline 12 & Corporate Bond & $53.55 \%$ & $20.50 \%$ \\
\hline
\end{tabular}

TABLE VIII: FACTORS THAT AFFECT TO SAVING AND NOT SAVING IN TOP 5 SAVING DECISION

\begin{tabular}{|l|l|l|l|}
\hline & $\begin{array}{l}\text { Saving } \\
\text { Type }\end{array}$ & Reason to save & Reason not to save \\
\hline 1. & Bank & $\begin{array}{l}\text { Convenience, fast, } \\
\text { Low risk }\end{array}$ & Low return \\
\hline 2. & Insurance & $\begin{array}{l}\text { Risk Management, } \\
\text { Tax purpose }\end{array}$ & $\begin{array}{l}\text { Afraid of insurance co. } \\
\text { bankruptcy, } \\
\text { Not enough money }\end{array}$ \\
\hline 3. & Gold & $\begin{array}{l}\text { Dressing, } \\
\text { Easy to trade (more } \\
\text { liquidity) }\end{array}$ & $\begin{array}{l}\text { Afraid of loss } \\
\text { Not enough money }\end{array}$ \\
\hline 4. & $\begin{array}{l}\text { Real } \\
\text { Estate }\end{array}$ & $\begin{array}{l}\text { For living purpose, } \\
\text { Inflation hedging }\end{array}$ & $\begin{array}{l}\text { Not necessary yet, } \\
\text { Not enough money } \\
\text { /high risk }\end{array}$ \\
\hline
\end{tabular}

TABLE IX: FACTORS THAT AFFECT TO SAVE AND NOT TO SAVE FOR THE SECOND GROUP

\begin{tabular}{|c|l|l|l|}
\hline 1. & $\begin{array}{l}\text { Banker } \\
\text { Acceptance }\end{array}$ & $\begin{array}{l}\text { Low risk, } \\
\text { Higher return than bank } \\
\text { saving }\end{array}$ & $\begin{array}{l}\text { Have other better } \\
\text { alternative, } \\
\text { Afraid of bank } \\
\text { bankruptcy }\end{array}$ \\
\hline 2 & $\begin{array}{l}\text { Corporate } \\
\text { Equity }\end{array}$ & $\begin{array}{l}\text { Higher return than bank } \\
\text { saving, Acceptable risk }\end{array}$ & $\begin{array}{l}\text { Afraid of } \\
\text { corporate } \\
\text { bankruptcy, } \\
\text { High risk, } \\
\text { Afraid of loss }\end{array}$ \\
\hline 3 & $\begin{array}{l}\text { Fixed } \\
\text { income fund }\end{array}$ & $\begin{array}{l}\text { Tax incentive, } \\
\text { Higher return than bank } \\
\text { saving }\end{array}$ & $\begin{array}{l}\text { Unknowledgeable, } \\
\text { Have other better } \\
\text { alternative }\end{array}$ \\
\hline 4. & Equity fund & $\begin{array}{l}\text { Tax incentive } \\
\text { Can choose level of risk }\end{array}$ & $\begin{array}{l}\text { Unknowledgeable, } \\
\text { Afraid of capital } \\
\text { loss }\end{array}$ \\
\hline 5. & $\begin{array}{l}\text { Common } \\
\text { Stock }\end{array}$ & $\begin{array}{l}\text { Hope for capital gain } \\
\text { dividend }\end{array}$ & $\begin{array}{l}\text { Afraid of loss, } \\
\text { Unknowledgeable, }\end{array}$ \\
\hline 6 & $\begin{array}{l}\text { Government } \\
\text { Bond }\end{array}$ & $\begin{array}{l}\text { Secure } \\
\text { Higher return than bank } \\
\text { saving }\end{array}$ & $\begin{array}{l}\text { Afraid of lossa } \\
\text { Not enough } \\
\text { money }\end{array}$ \\
\hline 7. & $\begin{array}{l}\text { Saving with } \\
\text { cooperative } \\
\text { Higher return than bank } \\
\text { saving, convenience } \\
\text { location) }\end{array}$ & $\begin{array}{l}\text { Hope to win the lottery, } \\
\text { Not lose initial investment } \\
\text { near by }\end{array}$ & $\begin{array}{l}\text { Low return, } \\
\text { Unknowledgeable, }\end{array}$ \\
\hline
\end{tabular}




\section{Factor Affect to Save and not to Save Decision}

Table VIII and Table IX shows reason that savers choose to answer why they decide to save and not to save into particular saving forms.

\section{E. Saving Allocation}

Table $\mathrm{X}$ shows saving allocation amongst various saving forms. We find that from 100 percent of disposable income, all together only 17.30 percent of their money are allocated into 4 types of securities; mutual fund, common stock, government bond, and corporate bond. The most allocated saving form is into real estate, 24.20 percent, because property is basic need for human and investing in property can be viewed as hedging against inflation. About 21.47 percent is allocated into saving with bank. This reflect the saver sentiment in Thailand which familiar with classic saving with bank because its convenience, easy to access and low risk. The third in this category is buying insurance which is 11.63 percent. The purpose is for risk management.

TABLE X: SAVing Allocations (PeRCENTAGe of Money Allocation)

\begin{tabular}{|c|c|}
\hline Saving Type & $(\%)$ \\
\hline Real estate & $24.20 \%$ \\
\hline Saving with bank & $21.47 \%$ \\
\hline Insurance & $11.63 \%$ \\
\hline Cooperative & $9.79 \%$ \\
\hline Gold & $7.62 \%$ \\
\hline Mutual fund (Equity and Fixed income fund) & $6.48 \%$ \\
\hline Common Stock & $5.97 \%$ \\
\hline Saving Lottery & $5.87 \%$ \\
\hline Government Bond & $3.35 \%$ \\
\hline Corporate Bond & $1.50 \%$ \\
\hline Others & $1.31 \%$ \\
\hline Banker Acceptances & $0.79 \%$ \\
\hline
\end{tabular}

\section{F. Understanding Risk-Return Concept}

TABLE XI: SAVERS PERCEPTION OF RISK FROM LEAST RISK TO HIGHEST RISK (1=LEAST, 5= MOST)

\begin{tabular}{|c|c|}
\hline \multicolumn{2}{|c|}{ RISK $(1=$ LEAST, $=$ MOST $)$} \\
\hline Saving with Bank & 1.3 \\
\hline Cooperative & 1.6 \\
\hline Government bond & 1.8 \\
\hline Cooperative & 2.0 \\
\hline Insurance & 2.3 \\
\hline Gold & 2.5 \\
\hline Banker acceptance & 2.7 \\
\hline Real estate & 2.7 \\
\hline Mutual fund & 3.0 \\
\hline Corporate bond & 3.7 \\
\hline Common Stock & 3.7 \\
\hline
\end{tabular}

About 52.8 percent of savers answer they are understand, 0.8 percent are very well understand, 43.4 percent are fairly understand, while only 3 percent do not understand risk-return trade-off concept. The savers rank their risk return perception of saving forms from least to most as see in Table XI and Table XII. The results show that savers perceive that saving with bank is the least risk and invest in financial securities (e.g. mutual fund, corporate debt, and common stock) pertain more risk than other saving types. Savers expect to get more return from investing in corporate debt and common stock. Savers perceived that invest in real estate and gold has low risk but get similar return to other financial securities such as mutual fund, corporate debt and common stock. Hence, saver tends to invest in real estate and gold.

The result show that saver give their opinion that saving with bank is the least risk and investing in securities in financial market such as mutual fund, bond and stock are riskier than other type of investment. Another interesting point is that, saver perceive that investing in some tangible asset has less risk than investing in financial assets. They believe that investing in real estate and gold has less risk but get similar return to investing in mutual fund, stock and bond.

TABLE XII: SAVERS PERCEPTION OF RETURN FROM THE LEAST TO THE

\begin{tabular}{|c|c|}
\hline \multicolumn{2}{|c|}{ MosT (LEAST $=1$, MOST = 5) } \\
\hline Saving with bank & 1.7 \\
\hline Lottery Saving & 2.3 \\
\hline Cooperative & 2.5 \\
\hline Government bond & 2.6 \\
\hline Insurance & 2.8 \\
\hline Banker acceptance & 2.8 \\
\hline Mutual fund & 2.9 \\
\hline Corporate bond & 3.2 \\
\hline Real estate & 3.4 \\
\hline Common stock & 3.4 \\
\hline Gold & 3.5 \\
\hline
\end{tabular}

Hence, saver are interested in investing in real estate than financial assets which is quite contradicted to the fact that price of real estate and gold are more volatile than financial asset. However, we might conclude that saver well understand risk return concept, since they can separate high risk saving type from low risk saving type.

\section{CONCLUSION AND RECOMMENDATION}

This paper found that saving via financial instruments in capital market is low. If regulator and financial institutions eliminate the obstacle that makes people not to choose to invest in that particular instrument, there will be more opportunity for saver to get into financial markets as the following:

1) Some savers do not invest in some instrument because the minimum requirement for invest is too high so financial institutions can make the initial investment smaller and will promote more individual investor into the market e.g. government bond

2) Some savers do not buy insurance, corporate bond, and banker acceptance because they afraid that the issue will default or in the case of stock and government bond they afraid of losing the value of their investment. This reveals that although savers have high education and 
know the financial instruments but they are not sufficiently understand principle of investment. It is also difficult to analyze and understand the complex financial instrument for savers and investor feels anxiety to about the uncertainty of their return. So they tend to be conservative and do not take more risk. Hence if financial institution promote and give knowledge about their financial instrument and give them confident in investing, this will help to promote the development of capital market as a whole.

The result show that saver decision in Thailand in investing in financial instruments such as mutual fund, corporate bond, equity fund (including Retirement Mutual Fund or RMF and Long term Investment Fund or LTF) and insurance resulting from tax advantage. Hence, regulator should not abolish the tax advantage to investor.

The result show that family has more effect to saving decision and bank staff also influence saving decision because bank branch is quite convenience to saver. Hence bank staff should give more knowledge to investor or should they have professional at their bank branch to give investor information.

Although saving with bank give lower return to saver but saver still choose to save with bank rather than invest into other financial instruments that give higher return. The reason is their convenience. There are wide spread of bank branches everywhere in Thailand even in the shopping mall. The saver feel that they cannot invest much into other financial instruments because its inconvenience. Hence, if financial institution improves their selling channel to reach investor, will help savers to reach more to capital market.

\section{ACKNOWLEDGMENT}

This research is sponsored by Integrated Innovation Academic Center: IIAC Chulalongkorn University Centenary Academic Development Project and the higher Education Research Promotion and National Research University Project of Thailand, Office of the higher Education Commission) (CU56-HS09). The authors would like to thank you to Associate Professor Patcharavalai Jayapani, Associate Professor Methinee Vanikkul and Rattachai Silacharoen for their helps to complete the research.

\section{REFERENCES}

[1] Global Health and Aging, National Institute on Aging, National Instiotutes of Health, World Health Organization, 2011.

[2] National Account, Office of the National Economic and Social Development Board, 2012

[3] K. S. Hebbel and L. Serven, "Does income inequality raise aggregate saving?" Journal of Development Economics, vol. 61, pp. 415-46, 2000.

[4] F. Hayashi, "Test for liquidity constraints: A critical survey and some new observations," in Proc. the Advances in Econometrics, Fifth World Congress, 1987, vol. 2, pp. 91-120.

[5] S. Zeldes, "Consumption and liquidity constraints: An empirical investigation," Journal of Political Economy, vol. 97, pp. 305-346, 1989.
[6] D. E. Rundel, "Liquidity constraints and the permanent-income hypothesis: Evidence frompanel data," Journal of Monetary Economics, vol. 27. 1991.

[7] A. F. Shorrocks, "The age-wealth relationship: A cross-section and cohort analysis," Review of Economic Statistic, vol. 57, pp. 155-163, 1957.

[8] G. Katona, Psychological Economics, New York: Elsevier. 1975.

[9] G. J. Doornbos and W. F. van Raaij, "The impact of economic conditions and expectations on household saving," in Proc. 16th CIRET Conference, CIRET Study Nr, 34, Munich: IFO Institute for Economic Research, 1984, pp. 21-42.

[10] F. Modigliani, "The role of intergenerational transfers and life cycle saving in the accumulation of wealth," Journal of Economics Perspectives, vol. 2, no. 2, 1988.

[11] M. H. S. Hersh and R. H. Thaler. "The behavioral life-cycle hypothesis," Economic Inquiry, vol. 26, pp. 609-693, 1988.

[12] F. Modigliani and R. E. Brumberg, "Utility analysis and the consumption function: An interpretation of cross-section data," in Post-Keynesian Economics, K. K. Kurihara (Ed.) New Brunswick, NJ: Rutgers University Press, 1954, pp. 388-436.

[13] M. Friedman, A Theory of the Consumption Function, Princeton University Press, p. 259, 1957.

[14] R. E. Hall and F. S. Mishkin, "The sensitivity of consumption to transitory income: Estimate from panel data on households," Econometrica, vol. 50, pp. 461-481, 1982.

[15] B. R. Avery and A. B. Kennickell, "Household saving in the U.S." Review of Income and Wealth, vol. 37, issue 4, pp. 409-432, December, 1991.

[16] J. Crockett, "The Choice between spending and saving, selected aspects of consumer behavior-A Summary from the perspective of different disciplines," National Science Foundation, Washington, D.C. 1977.

[17] N. A. Jianakoplos, P. L. Menchik, and F. O. Irvine, "Saving behavior of older households: Rate-of-return, precautionary and inheritance effects," Economics Letters, Elsevier, vol. 50, no. 1, January 1996, pp. $111-120$

[18] T. Jappelli and M. Padula, "Investment in financial literacy and saving decisions," CSEF Working Papers 272, Center for Studies in Economics and Finance (CSEF), University of Naples, Italy, 2011

[19] U. Lundman, "Information and transactions on the stock market," EFI. Stockholm, 1969.

[20] R. Ferber, "Consumer economics-A survey," Journal of Economic Literature, vol. 11, no.4, pp. 1303-1342, December, 1973.

[21] L. R. Dennis and H. D. Granbois, "Determinants of role structure in family financial management," Journal of Consumer Research, pp. 253-58, 10 September, 1983.

[22] M. Mozzocco, "Saving, risk sharing and preferences for risk," The American Economic Review, vol. 94, no. 4, pp. 1169-1182, 2004.

[23] A. Lindqvist, "A note on determinants of household saving behavior," Journal of Economic Psychology, vol. 1, pp. 39-57, 1981.

[24] D. Park and K. Shin, "Saving, investment and current accounts surplus in developing Asia," Asian Development Bank Working Paper 158, 2009.

[25] J. Xiao and G. I. Olson "Mental accounting and saving behavior," Home Economics Research Journal, vol. 22, no. 1, pp. 92-109, 1993.

[26] P. Khrishnamra, C. Jayapani, M. Vanikkul, R. Silacharoen, and N. Suppakitjarak, "Household saving behavior in Bangkok and metropolitan," Chulalongkorn Business Review, vol. 33, no. 129, 2010.

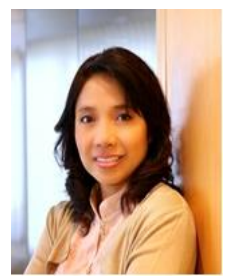

N. Suppakitjarak was born in Thailand. She received her M.B.A. and Ph.D. in Banking and Finance from the University of Birmingham, United Kingdom. She is currently a lecturer in department of Banking and Finance, Chulalongkorn University. Her research interests include financial markets, capital markets, bank management, saving behavior, and international portfolio diversification. 